\title{
B1 repetitive sequence methylation enhances wound healing of second-degree burns in rats
}

\author{
JIRAROCH MEEVASSANA ${ }^{1-3}$, PANUPONG NACHAROENKUL ${ }^{2}$, JADE WITITSUWANNAKUL ${ }^{4}$, \\ NAKARIN KITKUMTHORN ${ }^{5}$, KEVIN J. HAMILL ${ }^{6}$, APICHAI ANGSPATT ${ }^{2,3}$ and APIWAT MUTIRANGURA ${ }^{1}$ \\ ${ }^{1}$ Department of Anatomy, Center of Excellence in Molecular Genetics of Cancer and Human Disease, Faculty of Medicine; \\ ${ }^{2}$ Department of Surgery, Division of Plastic and Reconstructive Surgery, Faculty of Medicine; \\ ${ }^{3}$ Center of Excellence in Burn and Wound Care, Faculty of Medicine; ${ }^{4}$ Department of Medicine, Division of Dermatology, \\ Faculty of Medicine, Chulalongkorn University, Bangkok 10330; \\ ${ }^{5}$ Department of Oral Biology, Faculty of Dentistry, Mahidol University, Bangkok 10400, Thailand; \\ ${ }^{6}$ Institute of Life Course and Medical Sciences, Faculty of Health and Life Sciences, \\ University of Liverpool, Liverpool L69 7ZX, United Kingdom
}

Received September 10, 2021; Accepted December 22, 2021

DOI: $10.3892 /$ br.2022.1503

\begin{abstract}
The accumulation of DNA damage in burn wounds delays wound healing. DNA methylation by short interspersed nuclear element (SINE) small interfering (si) RNA prevents DNA damage and promotes cell proliferation. Therefore, SINE siRNA may be able to promote burn wound healing. Here, a SINE B1 siRNA was used to treat burn wounds in rats. Second-degree burn wounds were introduced on the backs of rats. The rats were then divided into three groups: a B1 siRNA-treated, saline-treated control, and saline + calcium phosphate-nanoparticle-treated control group ( $n=15 /$ group). The wounds were imaged on days 0,7 , 14, 21 and 28 post-injury. The tissue sections were processed for methylation, histological and immunohistochemical examination, and scored based on the overall expression of histone H2AX phosphorylated on serine $139(\gamma \mathrm{H} 2 \mathrm{AX})$ and
\end{abstract}

Correspondence to: Dr Jiraroch Meevassana, Center of Excellence in Burn and Wound Care, Faculty of Medicine, Chulalongkorn University, 254 Phayathai Road, Pathum Wan, Bangkok 10330, Thailand

E-mail: jiraroch.m@chula.ac.th

Abbreviations: 8-OHdG, 8-Hydroxy-2'-deoxyguanosine; $\gamma \mathrm{H} 2 \mathrm{AX}$, histone $\mathrm{H} 2 \mathrm{AX}$ phosphorylated on serine 139; ANOVA, analysis of variance; $\mathrm{Ca}-\mathrm{P}$, calcium phosphate; COBRA B1, combine bisulfite restriction analysis for B1 element; Dnmt, DNA methyltransferase; $\mathrm{H} \& \mathrm{E}$, hematoxylin and eosin; IRS, interspersed repetitive sequence; $\mathrm{mC}$, methylated loci; NSS, normal saline solution; PMNL, polymorphonuclear leukocyte; SINE, Short interspersed nuclear element; siRNA, small interfering RNA; uC, unmethylated loci

Key words: second-degree burn, B1 siRNA, wound healing, B1 interspersed repetitive element, B1 methylation, RNA-directed DNA methylation 8-hydroxy-2'-deoxyguanosine (8-OHdG). Burn wound closure improved in the B1 siRNA-treated group compared with that in the control group, especially from days 14-28 post-injury $(\mathrm{P}<0.001)$. The overall pathological score and degree of B1 methylation in the B1 siRNA-treated group improved significantly at days $14-28$ post-injury, with the maximum improvement observed on day $14(\mathrm{P}<0.01)$ compared with the NSS and Ca-P nanoparticle groups. Immunohistochemical staining revealed lower expression of $\gamma \mathrm{H} 2 \mathrm{AX}$ and $8-\mathrm{OHdG}$ in the B1 siRNA-treated group than in the control groups at days 14-28 post-injury; the maximum improvement was observed on days 14 and 21 . These data imply that administering SINE siRNA is a promising therapeutic option for managing second-degree burns.

\section{Introduction}

Burn wounds can cause severe clinical injuries, and delayed wound healing leads to infection, prolonged hospital stays, increased morbidity and $>250,000$ deaths annually in the United States of America alone (1). Researchers and clinicians are actively studying the application of new substances to improve burn-treatment outcomes.

Interspersed repetitive sequences (IRSs) are the primary contributor to the genome $(\sim 45 \%)$, and their methylation levels are crucial for preserving the stability of the genome (2). Mutation rates are increased in cells with IRS hypomethylation $(3,4)$. A short interspersed nuclear element (SINE) retrotransposon is a repetitive element of 85-500 bp in length. Two SINE families exist, namely the B1 (in mice, rats and hamsters) and Alu (in humans) families $(5,6)$. Similar to the Alu element, the B1 element in rodents stems from 7SL RNA, which is cytoplasmic RNA; it facilitates protein excretion as a part of the signal recognition particle (7). The B1 element assists in transcriptional regulation and DNA stability by binding to the Aryl hydrocarbon (dioxin) receptor, which is a ligand-activated transcription factor $(8,9)$; however, to the 
best of our knowledge, no study has reported a correlation between B1 element methylation and wound healing and epithelialization.

Epigenetic changes associated with chromatin re-organization can facilitate the transcription machinery and promote wound repair (10). Genomic hypomethylation is characterized by reduced methylation of the methyl groups at the 5 ' position of cytosine and plays crucial roles in important events such as aging, cancer and various skin diseases (11-14). Furthermore, current research shows that global hypomethylation is associated with delayed proliferation; in contrast, following increased Alu methylation, cells can tolerate toxic substances and decreased DNA damage responses, and show an enhanced proliferation rate (15). Regarding corneal ulcers, a previous study has shown that the expression levels of DNA methyltransferase 1 (Dnmt1) and Dnmt3a, which participate in the methylation process, are significantly upregulated during corneal epithelial healing (16). Therefore, decreased Dnmt1 expression and genomic hypomethylation defer corneal epithelial wound healing and block human corneal epithelial cell proliferation and migration. The roles of DNA methylation in rodents include considerably reducing the wound area and increasing the wound healing rate by increasing DNA Dnmt3a expression (16). Moreover, decreased DNMT1 expression is associated with a low rate of squamous skin cell proliferation, whereas increased DNMT1 expression is associated with rapid limb bud generation $(17,18)$. A previous study revealed an association between age and Alu hypomethylation (11). Positive associations have also been observed between Alu hypomethylation in blood cells and several aging phenotypes $(19,20)$. In addition, treating cells with Alu small-interfering RNA (siRNA) increased Alu methylation and enabled cells to better tolerate toxic substances and proliferate faster (15).

RNA-directed DNA methylation is a natural process through which RNA molecules, which are not translated into any proteins, direct the addition of methyl groups at the 5 ' position of cytosine specific to the RNA in CpG islands. These islands are genomic regions where $\mathrm{CpG}$ sites, DNA regions in which a cytosine nucleotide is followed by a guanine nucleotide, occur at a high frequency. The $\mathrm{CpG}$ islands are predominantly found in SINE repetitive sequences, such as Alu and B1 $(6,21)$. This process is facilitated by a cascade of enzymes, Dicer, RNA-induced silencing complex and Argonaute proteins $(21,22)$. This alternative pathway is initiated in chromatin within the nucleus, and leads to epigenetic modifications, including DNA cytosine methylation and histone methylation $(23,24)$.

Burns and heat stress can cause DNA damage in various cells and animals $(11,25-30)$ and result in DNA damage responses (31). For example, in heated germline cells, an increase in 8-hydroxy-2'-deoxyguanosine (8-OHdG) level was observed in response to DNA damage (32). Keratinocytes experience DNA damage and exhibit delayed proliferation and apoptosis after exposure to temperatures $>42^{\circ} \mathrm{C}$ for $24 \mathrm{~h}$ (33). Furthermore, an increase in histone $\mathrm{H} 2 \mathrm{AX}$ phosphorylation on serine 139 ( $\gamma \mathrm{H} 2 \mathrm{AX}$ ) occurs in response to reactive oxygen species-induced DNA double strand breaks, which have multiple causes, including irradiation, burns and laser exposure (34-36). There is a positive correlation between increasing the temperature from $41.5^{\circ} \mathrm{C}$ to $45.5^{\circ} \mathrm{C}$ with $\gamma \mathrm{H} 2 \mathrm{AX}$ levels in H1299 (human non-small-cell lung carcinoma p53-deficient) cells (27). Moreover, high temperature-induced formation of $\gamma$-H2AX foci may result in carcinogenesis (37).

The relationship between heat, burns and methylation has been studied previously (38-40). There is evidence that heat stress and high temperatures lower DNA methylation levels in pig muscles and fish tissues, specifically in the promoter regions of heat shock protein genes (41-43). An increase in the ambient temperature can affect Alu methylation in humans $(44,45)$. However, to best of our knowledge, no study has investigated the relationship between burn wound healing and Alu methylation with markers of genomic instability, as has been shown for 8-OHdG and $\gamma \mathrm{H} 2 \mathrm{AX}$.

Therefore, it was hypothesized that DNA methylation in IRSs can prevent DNA damage and accelerate burn wound healing in rats. In the present study, the role of B1 methylation in genomic instability in relation to wound healing was studied. The following questions were addressed: How can B1 methylation be restored to reduce genomic stability caused by heat, and how can the rate and quality of wound healing and epithelialization be accelerated and the quality improved.

\section{Materials and methods}

Animal experiments. Animal experiments were approved by the Animal Care and Use Committee of Chulalongkorn University (approval no. 012; March 03/2019).

A total of 45 8-week-old male Wistar rats (150-180 g) were obtained from Namura Animal Laboratory Center (Bangkok, Thailand). The rats were acclimated for 7 days under a controlled 12-h light/dark cycle, fed standard mice chow, and provided ad libitum access to water. To create second-degree burns, the rats were anesthetized with $2 \%$ isoflurane (Sigma-Aldrich; Merck KGaA) (45), and the dorsal skin was shaved. Two burn wounds were created on the back of each rat using a 10-mm-diameter aluminum rod, which was heated to $100^{\circ} \mathrm{C}$ and placed on the skin for $10 \mathrm{sec}(46)$. The rats were divided into three groups with 15 rats/group. Normal saline solution (NSS; $100 \mu \mathrm{l}$ ), calcium phosphate (Ca-P) nanoparticles, or $150 \mathrm{nM} \mathrm{B1}$ siRNA in $100 \mu \mathrm{l}$ of a solution containing $\mathrm{Ca}-\mathrm{P}$ nanoparticles was applied daily to each wound on the rats in the control and treatment groups.

The wounds of three animals in each group (a total of six) were imaged on days 0, 7, 14, 21 and 28 after injury, and the wound areas were measured using Image J version $1.52 \mathrm{t}$ (National Institutes of Health) with a freehand selection tool. Wound areas are reported as a percentage of the initial wounded area. The rats were euthanized by exposing them to $5 \%$ isoflurane for 5-10 min until respiration ceased and they were confirmed dead on day 28 (45). For 12 animals in each group (a total of 24 wounds), three rats (a total of six wounds) were euthanized with 5\% isoflurane on days 3, 7, 14 and 21 . On each of the specified euthanasia days, wound tissues were excised, and three of these samples (from the initial six wounds) were immediately subjected to DNA extraction and analyzed to determine the methylation levels. The remaining three wound tissues were fixed in $10 \%$ neutral-buffered formalin at room temperature $\left(28-30^{\circ} \mathrm{C}\right)$ for at least $48 \mathrm{~h}$ and embedded in paraffin for pathological examination (Fig. 1). 


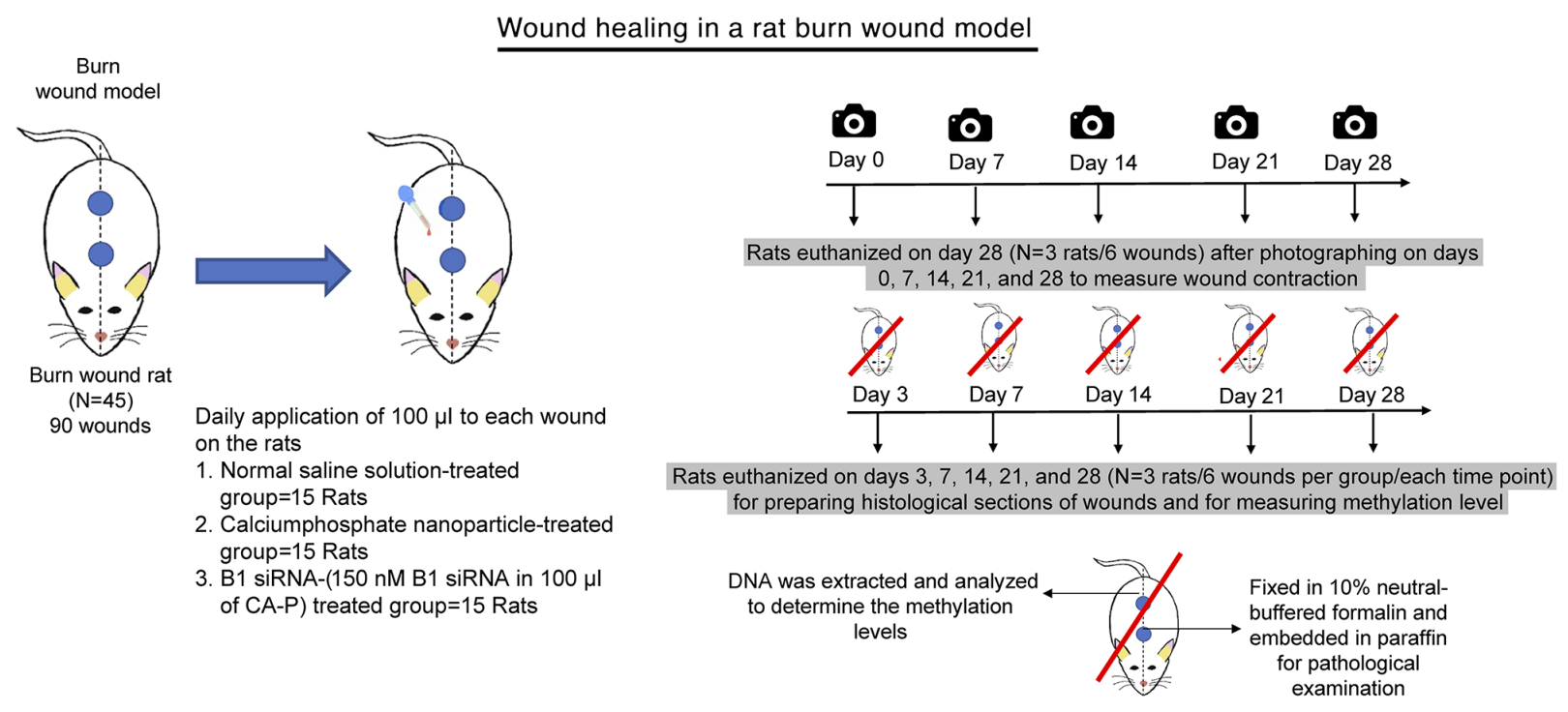

Figure 1. Integrated experimental design. siRNA, small interfering RNA.

Cells and cell culture. Rat epidermal keratinocytes (REK) (Cell Applications) were cultured in DMEM supplemented with $10 \%$ FBS, $100 \mathrm{U} / \mathrm{ml}$ penicillin and $100 \mathrm{mg} / \mathrm{ml}$ streptomycin (Thermo Fisher Scientific, Inc.). Cells were incubated at $37^{\circ} \mathrm{C}$ in a humidified incubator supplied with $95 \%$ air and $5 \% \mathrm{CO}_{2}$. The cells were cultured in T-75 Corning ${ }^{\mathrm{TM}} \mathrm{U}$-shaped cell culture flasks and harvested at a confluency of $\sim 80 \%$ using $0.05 \%$ Trypsin-EDTA with phenol red (Thermo Fisher Scientific, Inc.).

siRNA delivery using a nanoparticle-coating system. The B1 siRNA sequences were 5'-CGCACGCCUUUAAUCCCA GCACUCGUU-3' (sense) and 5'-CGAGUGCUGGGAUUA AAGGCGUGCGUU-3' (antisense). The scrambled siRNA sequences were 5'-GGCCAUUUCCCCGACUGCACACCU AUU-3' (sense) and 5'-UAGGUGUGCAGUCGGGGAAAU GGCCUU-3' (antisense). The B1 siRNAs and scrambled siRNA were purchased from Bioneer, Inc. The siRNA sequences were designed using siRNA wizard software version 3.1 (InvivoGen). The day before transfection, $5 \times 10^{4}$ REK cells/well were seeded in a 24-well plate in $0.5 \mathrm{ml}$ DMEM supplemented with $10 \%$ fetal bovine serum. After $24 \mathrm{~h}$, the medium in each well in the control groups was replaced with normal saline solution (NSS; $100 \mu \mathrm{l}$ ) and experiment groups was replaced with $100 \mu \mathrm{l}$ Ca-P nanoparticles, $150 \mathrm{nM}$ B1 siRNA in $100 \mu \mathrm{l}$ Ca-P nanoparticles and $150 \mathrm{nM}$ scramble siRNA in $100 \mu \mathrm{l}$ Ca-P nanoparticles. The cells were incubated at $37^{\circ} \mathrm{C}$ in a $\mathrm{CO}_{2}$ incubator for $48 \mathrm{~h}$, following which, the cells were collected through trypsinization.

To deliver siRNAs to target cells, the siRNAs were coated with a nanoparticle solution before topical administration on the burn wounds. The most effective siRNA:nanoparticle solution ratio was $150 \mathrm{nM}$ B1 siRNA in $100 \mu$ l CA-P nanoparticle solution, based on the results of previous studies $(15,47,48)$.

First, B1 siRNA was mixed with an appropriate proportion and concentration of calcium solution (MilliporeSigma), a B1 siRNA-binding reagent. Next, the B1 siRNA-calcium complex was added to a mixture of sodium carbonate $\left(\mathrm{Na}_{2} \mathrm{CO}_{3}\right.$; MilliporeSigma) and sodium dihydrogen phosphate monohydrate $\left(\mathrm{NaH}_{2} \mathrm{PO}_{4} \cdot \mathrm{H}_{2} \mathrm{O}\right.$; MilliporeSigma). After the B1 siRNA-coating process, the nanoparticle-coated B1 siRNAs were stored at room temperature $\left(28-30^{\circ} \mathrm{C}\right)$ and prepared on the day of use. The nanoparticle solution was composed $50 \mu \mathrm{l}$ of a mixture containing $0.5 \mathrm{M}$ calcium chloride $\left(\mathrm{CaCl}_{2}\right)$ solution (MilliporeSigma) and $150 \mathrm{nM}$ B1 siRNA $+50 \mu \mathrm{l}$ of a mixture of $0.01 \mathrm{M} \mathrm{Na}_{2} \mathrm{CO}_{3}$ solution (MilliporeSigma) and $0.01 \mathrm{M} \mathrm{NaH}_{2} \mathrm{PO}_{4} \cdot \mathrm{H}_{2} \mathrm{O}$ solution (MilliporeSigma). A 31:1 molar ratio of $\mathrm{CO}_{3}{ }^{2-}: \mathrm{PO}_{4}{ }^{3-}$ was used. The B1 siRNA was mixed with $16 \mu 10.5 \mathrm{M} \mathrm{CaCl}_{2}$ solution and adjusted to a final volume of $50 \mu \mathrm{l}$ using sterile $\mathrm{dH}_{2} \mathrm{O}$. Thereafter, the $\mathrm{B} 1$ siRNA-calcium complex was added to $50 \mu \mathrm{l}$ of a mixture of $\mathrm{Na}_{2} \mathrm{CO}_{3}$ solution and $\mathrm{NaH}_{2} \mathrm{PO}_{4} \cdot \mathrm{H}_{2} \mathrm{O}$ solution $(16 \mu \mathrm{l})$ and $34 \mu \mathrm{l}$ sterile $\mathrm{dH}_{2} \mathrm{O}$ (47). All steps in the preparation of the nanoparticle solution were performed using sterile techniques. Each nanoparticle solution preparation was used to validate the transfection efficiency with rat dermal keratinocytes (Cell Applications) before each experiment (48-52).

Histopathology and immunohistochemistry. Formalin-fixed wound tissues were dehydrated and embedded in paraffin, after which, 3- $\mu \mathrm{m}$-thick sections were prepared using a microtome. Hematoxylin and eosin (H\&E) staining was performed for scoring, using hematoxylin solution for $6 \mathrm{~h}$ and eosin $\mathrm{Y}$ ethanol solution for $48 \mathrm{~h}$ at a temperature of $60^{\circ} \mathrm{C}$. Immunohistochemical staining of the tissue sections was performed using monoclonal antibodies against $\gamma \mathrm{H} 2 \mathrm{AX}$ (1:100; cat. no. Ab2893; Abcam) and 8-OHdG (1:100; cat. no. Ab48508; Abcam) (53). The sections and antibodies were incubated at $37^{\circ} \mathrm{C}$ for $32 \mathrm{~min}$ using the Ventana ${ }^{\circledR}$ Benchmark XT (Ventana Medical Systems, Inc; Roche Diagnostics) automated slide strainer in combination with the Ventana ultraView DAB v3 IHC Detection Kit before mounting, according to the manufacturer's protocol. Thereafter, the slides were counterstained at $25^{\circ} \mathrm{C}$ with Hematoxylin II for 8 min and Bluing Reagent for 4 min (53).

The histological sections of the wounds were graded using a histopathological scoring system, following a previously published method with some modifications (54-58) Three dermatopathologists who were blinded to the treatment regimen independently performed H\&E scoring, based on five criteria: Epithelialization, polymorphonuclear leukocyte 
A
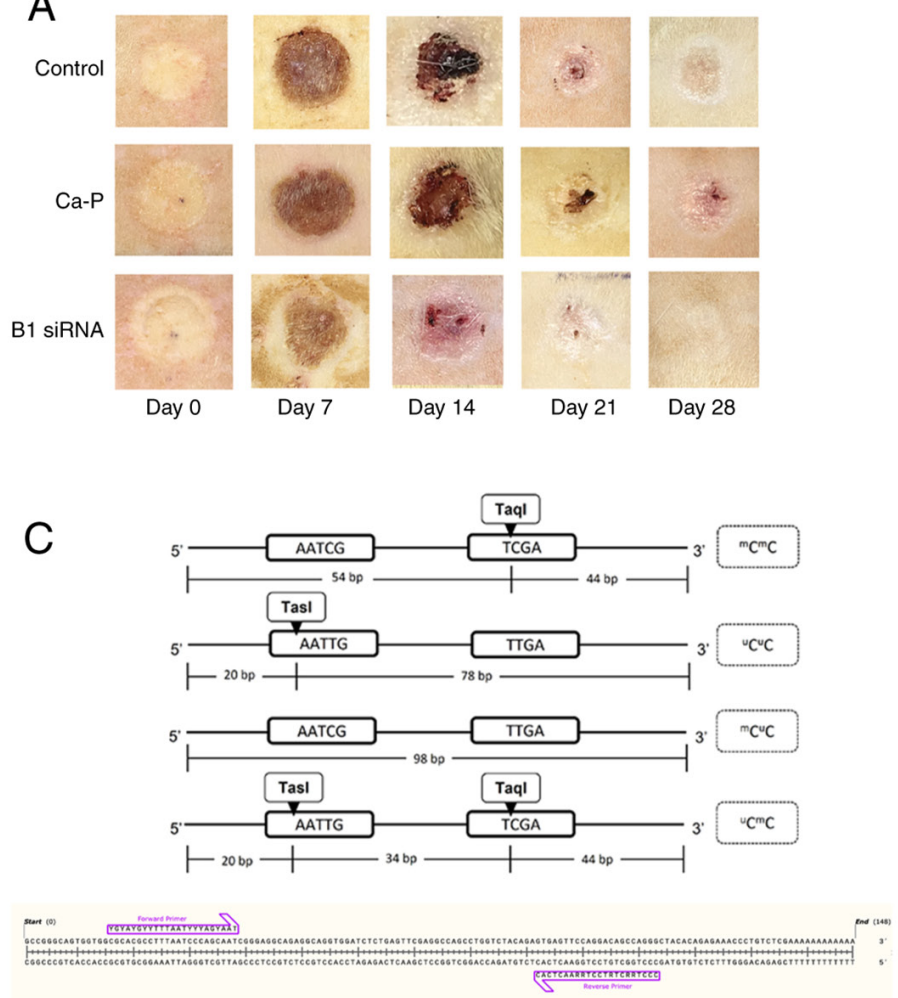
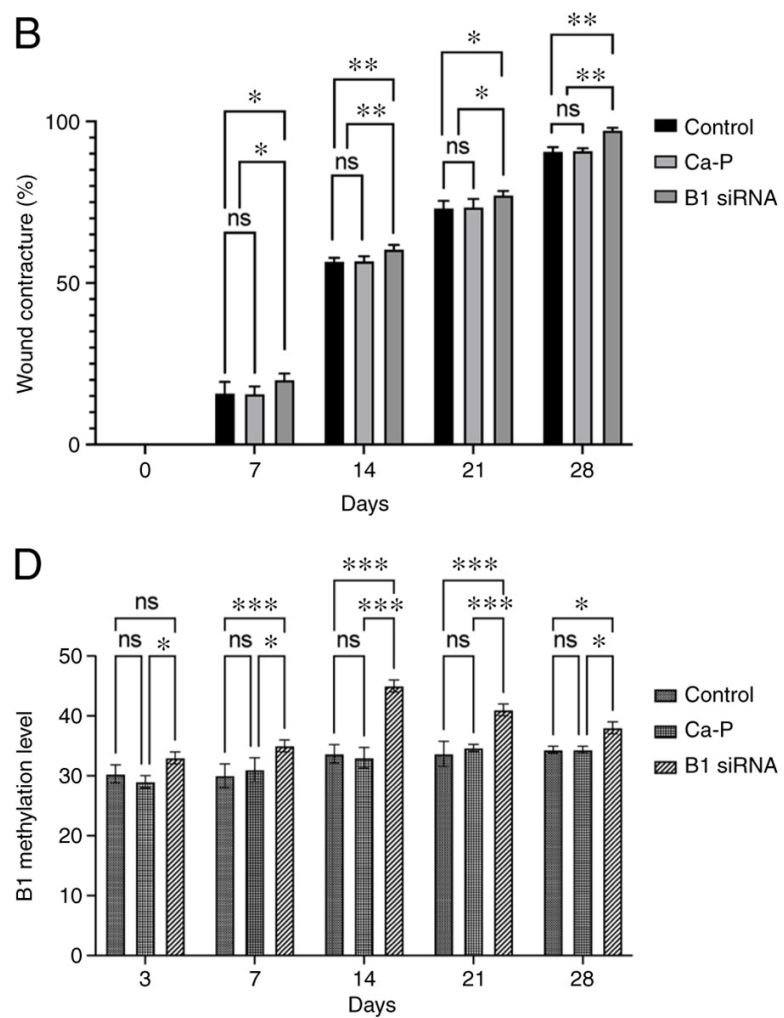

Figure 2. Effect of B1 siRNA treatment on the contracture rate of second-degree burn wounds. (A) Images of second-degree burn wounds in rats whose wounds were treated daily with a saline control, Ca-P nanoparticles or B1 siRNA. The wounds treated with B1 siRNA exhibited increased contraction and less inflammation compared with both controls. (B) Wound healing plotted as a percentage of the original wound area. Wound healing was significantly enhanced in the B1 siRNA-treated group compared with that in the control groups, especially on days 14 and 28 post-injury (Kruskal-Wallis test). (C) The methylation patterns of B1 detected by COBRA-B1, and the restriction enzyme digest sites. (D) The B1 methylation level of second-degree burn wounds. B1 methylation was significantly enhanced in the treated group compared with that in the control group, especially on days 7,14 and 21 post-injury (one-way ANOVA). ${ }^{*} \mathrm{P}<0.05,{ }^{* *} \mathrm{P}<0.01,{ }^{* * *} \mathrm{P}<0.001$. $\mathrm{n}=6$ wounds/group. siRNA, small interfering RNA; COBRA B1, combine bisulfite restriction analysis for B1 element; ns, not significant; Ca-P, calcium phosphate.

(PMNL) infiltration, collagen formation, number of fibroblasts and presence of new blood vessels. A score of 0 was assigned when there was no evident epithelialization and no increase in the number of fibroblasts, PMNLs or newly formed blood vessels. A score of 1 indicated an increased thickness of the edges of the cut epithelial tissue sections, or the presence of a few fibroblasts, PMNLs and newly formed blood vessels. A score of 2 indicated migration of epithelial cells, or the presence of a moderate number of fibroblasts, PMNLs and newly formed blood vessels. A score of 3 indicated epithelial bridging of the incision, or the presence of several fibroblasts, PMNLs and newly formed blood vessels. A score of 4 was assigned for sections where there was complete regeneration of the epithelium, or presence of excessive fibroblasts, PMNLs and newly formed blood vessels. The mean scores of the three scorers were determined and combined to obtain an overall pathology score. Sections positive for anti-cytokeratin immunohistochemical staining were scored in a similar manner; three dermatopathologists scoring the sections on a scale of $0-4$, starting from no staining to strong staining.

DNA preparation. DNA extraction from rat skin was performed using the phenol-chloroform method, which is the most commonly used method to purify and concentrate DNA (59), followed by the addition of phenol-chloroform to a solution of lysed cells, and mixing and separation of the two phases by centrifugation for $5 \mathrm{~min}$ at $16,000 \mathrm{x} \mathrm{g}$. The resulting solution was separated into two phases: A lower organic phase and an upper aqueous phase. The top aqueous phase containing DNA was then carefully removed. A total of $1 \mu 120 \mathrm{mg} / \mathrm{ml}$ Glycogen solution, $0.1 X 3 \mathrm{M}$ sodium acetate and $2.5 \mathrm{X}$ volume of absolute ethanol (100\%) were added to the precipitated DNA, and the mixture was centrifuged for $1 \mathrm{~min}$ at $8,000 \mathrm{xg}$ at $25^{\circ} \mathrm{C}$. Finally, the DNA was washed with $70 \%$ ethanol, air-dried and dissolved in $\mathrm{dH}_{2} \mathrm{O}(59)$.

Quantitative combined bisulfite restriction analysis for B1 element (COBRA B1). A total of $1 \mu$ l bisulfited DNA taken from an EZ DNA methylation-Gold ${ }^{\mathrm{TM}}$ kit (Zymo Research Corp.) was subjected to 45 cycles of PCR, using the PCR master$\mathrm{mix}^{\mathrm{TM}}$ (Thermo Scientific, Inc.). The following thermocycling conditions were used: $95^{\circ} \mathrm{C}$ for $15 \mathrm{~min}$; followed by 40 cycles at $95^{\circ} \mathrm{C}$ for $45 \mathrm{sec}, 53^{\circ} \mathrm{C}$ for $45 \mathrm{sec}$ and $72^{\circ} \mathrm{C}$ for $45 \mathrm{sec}$; with a final extension step of $72^{\circ} \mathrm{C}$ for $10 \mathrm{~min}$ using the B1 COBRA forward primer, 5'-YGYAYGYYTTTAATYYYAGYAAT-3' and reverse primer, 5'-CCCTRRCTRTCCTRRAACTCAC-3', which were designed using Primer 3 version 4.1.0 $(2,60)$, and had an annealing temperature of $70^{\circ} \mathrm{C}$. Primer sequences with ' $\mathrm{Y}$ ' represent pyrimidine bases $(\mathrm{C}$ or $\mathrm{T})$ that have the ability to bind to $G$ or A bases, and ' $R$ ' represents purine bases (A or $G$ ) that have the ability to bind to $\mathrm{T}$ or $\mathrm{C}$ bases in DNA sequences following bisulfite conversion (Fig. 2C). The amplified PCR 
products were digested with two units of Taql and Tasl endonuclease in NE buffer II (MBI Fermentas; Thermo Fisher Scientific, Inc.) at $37^{\circ} \mathrm{C}$ overnight. The digested PCR products were identified using $8 \%$ non-denaturing polyacrylamide gel electrophoresis and stained with SYBR Green JumpStart Taq ReadyMix (Sigma-Aldrich; Merck KGaA). All samples were assessed in duplicate. After enzyme digestion, six products of different lengths were detected after COBRA B1 $(98,78$, $54,44,34$ and $20 \mathrm{bp}$ ). The band intensities of the COBRA B1 products were determined using Image Quant version 8.2 (Molecular Dynamics; GE Healthcare).

Sequences of $B 1$ repetitive elements in rats and locations of the Taq1 and Tasl restriction enzyme sites. According to the B1 analysis and calculations, two types of COBRA B1 products could be classified based on the methylation status of the $\mathrm{CpG}$ dinucleotides, namely methylated loci $(\mathrm{mC})$ and unmethylated loci $(\mathrm{uC})$. The percentage of B1 methylation was calculated as follows. The letters demonstrated the normalized scores of each band, and the percentage of intensity of each band was divided by the amplicon length in terms of bp: $\% 98 / 98=\mathrm{A}$, $\% 78 / 74=B, \% 54 / 54=C, \% 44 / 42=D, \% 34 / 34=E$, and $\% 20 / 20=F$. Subsequently, the percentage of methylation was calculated by bring the normalized scores of the digested methylation fragment divided by the sum of the normalized scores of the undigested and digested products as following formula: $\%$ total methylation $(\% \mathrm{mC})=100 \times(\mathrm{A}+\mathrm{C}+\mathrm{D}) / 2 \mathrm{~A}+2 \mathrm{~B}+2 \mathrm{D}$. As an internal control, 25\% methylated rat genomic DNA (EpigenDX) was used for the experiments and inter-assay adjustment.

Statistical analysis. Distribution of data were determined using a Shapiro-Wilk test. For normally distributed data, a one-way ANOVA followed by Bonferroni post-hoc corrections were used to compare the groups. For non-normally distributed data, a Kruskal-Wallis analysis followed by a Dunn's post-hoc test was used to test the differences between groups. Data are reported as the mean \pm standard deviation. GraphPad Prism version 9.0.0 (GraphPad Software, Inc.) was used for all statistical analyses. $\mathrm{P}<0.05$ was considered to indicate a statistically significant difference.

\section{Results}

Treatment with B1 siRNA increases the rate of healing of second-degree burn wounds as well as the methylation levels in the wounds. Second-degree burn wounds were treated each day with $150 \mathrm{nM}$ B1 siRNA and the wound areas were measured using photographs taken on days $0,7,14,21$ and 28 post-injury (Fig. 2A). The improvements in wound healing were greater in the B1 siRNA group. The respective percentage wound healing \pm standard deviation in the groups treated with saline or Ca-P nanoparticles, relative to that in the B1 siRNA-treated group, on different days was as follows: i) Day $7,15.81 \pm 3.59$ and $15.66 \pm 2.36$ vs. $20.01 \pm 1.97 \%$, both $\mathrm{P}<0.01$; ii) day $14,56.58 \pm 1.24$ and $56.73 \pm 1.56$ vs. $60.38 \pm 1.39 \%$, both $\mathrm{P}<0.001$; iii) day $21,73.14 \pm 2.27$ and $73.39 \pm 2.62$ vs. $77.15 \pm 1.32 \%$, both $\mathrm{P}<0.01$; and iv) day $28,90.63 \pm 1.39$ and $90.81 \pm 0.86$ vs. $97.21 \pm 0.84 \%$, both $\mathrm{P}<0.001$. There were no differences in wound areas between the NSS-treated control and $\mathrm{Ca}-\mathrm{P}$ nanoparticle groups. Furthermore, significant differences were observed amongst the control and $\mathrm{Ca}-\mathrm{P}$ nanoparticle compared with the B1 siRNA treatment group, particularly on days 14 and 28 post-injury (Fig. 2B).

B1 siRNA promotes methylation through siRNA directed DNA methylation $(21,23)$; it improves DNA stability and enhances cell proliferation (15). The methylation levels of the B1 siRNA-treated group were significantly higher than those of the saline-treated control and Ca-P nanoparticle groups, especially on days 7 and 14 . The respective percentage methylation \pm standard deviation in the NSS control, Ca-P nanoparticle and B1 siRNA-treated wounds on different days were: i) Day 3, 30.33 \pm 1.52 and $29.0 \pm 1.0$ vs. $33.00 \pm 1.0 \%$, both $\mathrm{P}<0.05$; ii) day $7,30.0 \pm 2.0$ and $31.0 \pm 2.0$ vs. $35.0 \pm 1.0 \%$, both $\mathrm{P}<0.001$; iii) day $14,33.67 \pm 1.52$ and $33.0 \pm 1.73$ vs. $45.0 \pm 1.0 \%$, both $\mathrm{P}<0.001$; iv) day $21,33.67 \pm 2.08$ and $34.67 \pm 0.58$ vs. $41.0 \pm 1.0 \%$, both $\mathrm{P}<0.001$; and v) day $28,34.33 \pm 0.58$ and $34.33 \pm 0.58$ vs. $38.00 \pm 1.00 \%$, both $\mathrm{P}<0.05$ (Fig. 2D). Significant differences were observed in the B1 siRNA treated group compared with the control groups 3 days post-injury.

Pathological and immunohistochemical skin changes in the rat model of burn wounding. Individual histopathological scores were added together to provide an overall score for each wound. Blinded scoring of the wounds by the three dermatopathologists confirmed that the rats treated with B1 siRNA displayed considerably higher pathological scores than those treated with NSS or Ca-P nanoparticles, with the greatest improvement observed on days 14, 21 and 28 post injury. The pathological scores \pm standard deviation in the NSS and $\mathrm{Ca}-\mathrm{P}$ nanoparticle-treated groups (respectively), relative to that in the B1 siRNA-treated group, on different days were as follows: i) Day 3, $1.33 \pm 0.58$ and $1.67 \pm 0.58$ vs. $2.67 \pm 0.58 \%$, both $\mathrm{P}>0.05$; ii) day $7,7.67 \pm 1.16$ and $7.67 \pm 0.58$ vs. $7.0 \pm 1.0 \%$, both $\mathrm{P}>0.05$; iii) day $14,12.33 \pm 0.58$ and $11.33 \pm 1.16$ vs. $15.67 \pm 0.58 \%$, both $\mathrm{P}<0.01$; iv) day $21,13.33 \pm 0.58$ and $12.33 \pm 1.52$ vs. $16.0 \pm 0.0 \%, \mathrm{P}<0.05$; and v) day $28,15.0 \pm 1.0$ and $14.33 \pm 0.58$ vs. $16.67 \pm 1.53 \%, \mathrm{P}<0.05$ (Fig. $3 \mathrm{~A}$ and $\mathrm{B}$ ).

8-OHdG and $\gamma \mathrm{H} 2 \mathrm{AX}$ scores were determined to measure DNA damage response after introducing burn injuries. A low immunohistochemistry score for 8-OHdG and $\gamma \mathrm{H} 2 \mathrm{AX}$ reflected a low DNA damage response. The B1 siRNA-treated group exhibited lower levels of $8-\mathrm{OHdG}$ than the NSS and Ca-P nanoparticle groups on days 14 and 21 . In addition, the wounds in the B1 siRNA-treated group showed significantly lower $\gamma \mathrm{H} 2 \mathrm{AX}$ levels from days 7 to 21 than the NSS- and Ca-P nanoparticle-treated groups, with the highest level observed 14 days post-injury. The respective $8-\mathrm{OHdG}$ immunohistochemistry score \pm standard deviation in the NSS and Ca-P nanoparticle-treated groups (respectively), relative to that in the B1 siRNA-treated group was as follows: i) Day 3; $4.0 \pm 0.0$ and $4.0 \pm 0.0$ vs. $4.0 \pm 0.0 \%$, both $P>0.05$; ii) day $7 ; 4.0 \pm 0.0$ and $3.67 \pm 0.58$ vs. $3.33 \pm 0.58 \%$, both $\mathrm{P}>0.05$; iii) day $14,3.0 \pm 0.0$ and $3.33 \pm 0.58$ vs. $2.67 \pm 0.58 \%$; both $\mathrm{P}<0.01$; iv) day $21,3.0 \pm 0.0$ and $2.67 \pm 0.58$ vs. $2.0 \% \pm 0.0 \%$, both $\mathrm{P}<0.05$; and v) day $28,2.0 \pm 0.0$ and $2.0 \pm 0.0$ vs. $1.67 \pm 0.58 \%, \mathrm{P}<0.05$ (Fig. $3 \mathrm{C}$ and D). Furthermore, the $\gamma \mathrm{H} 2 \mathrm{AX}$ immunohistochemistry scores \pm standard deviation in the NSS and Ca-P nanoparticle groups, relative to that in the B1 siRNA-treated group, was as follows: i) day 3, 4.0 0.0 and $4.0 \pm 0.0$ vs. $4.0 \pm 0.0 \%$, both $\mathrm{P}>0.05$, ii) day $7,3.67 \pm 0.58$ and 
A

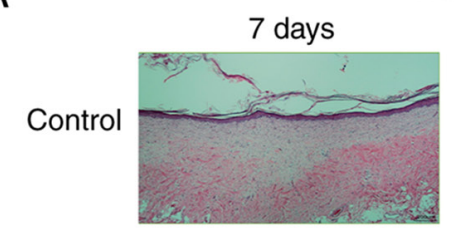

Ca-P

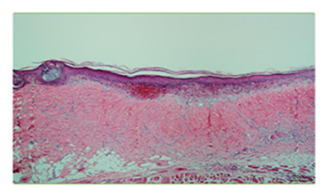

SiRNA
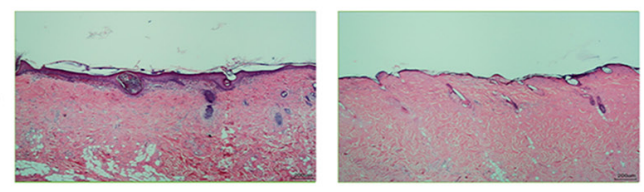

8-OHdG

C
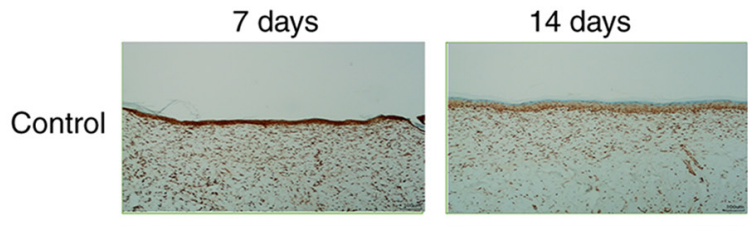

Ca-P

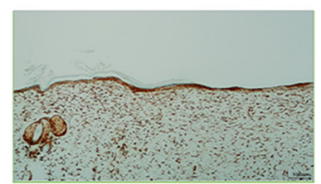

SiRNA
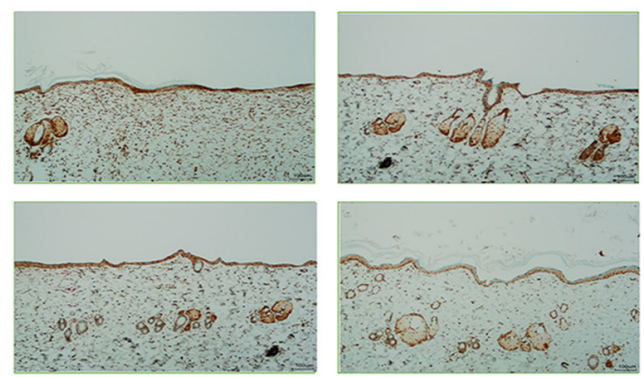

E
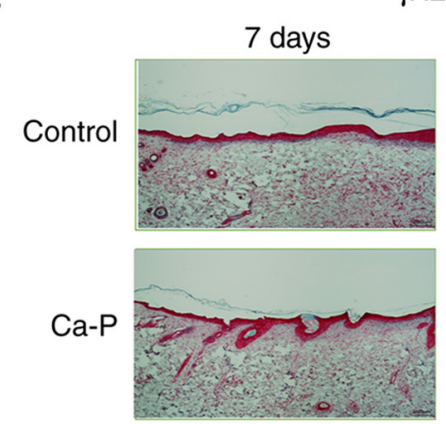

SiRNA

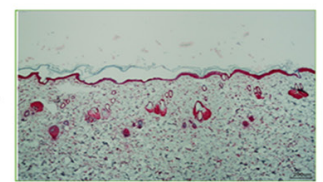

$\gamma \mathrm{H} 2 \mathrm{AX}$
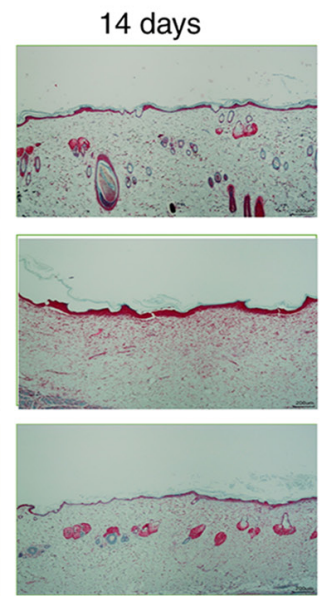

B

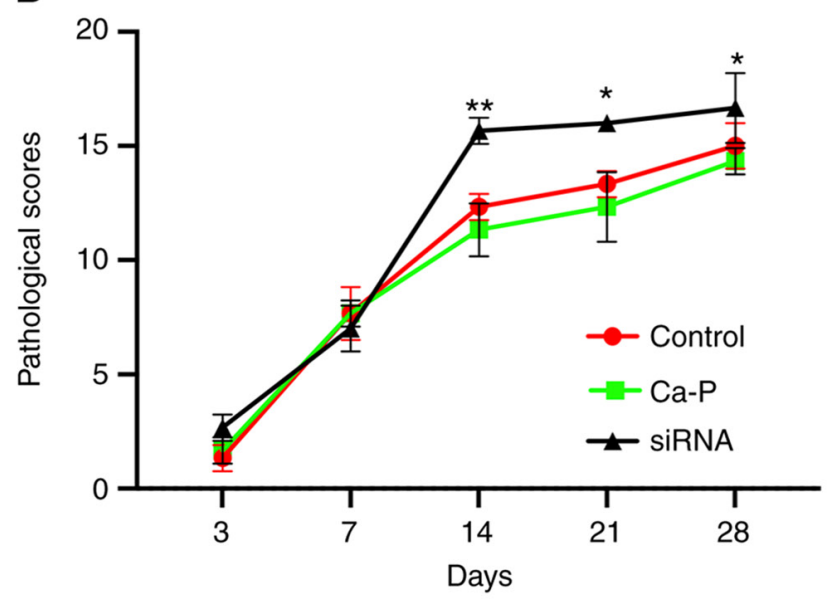

D

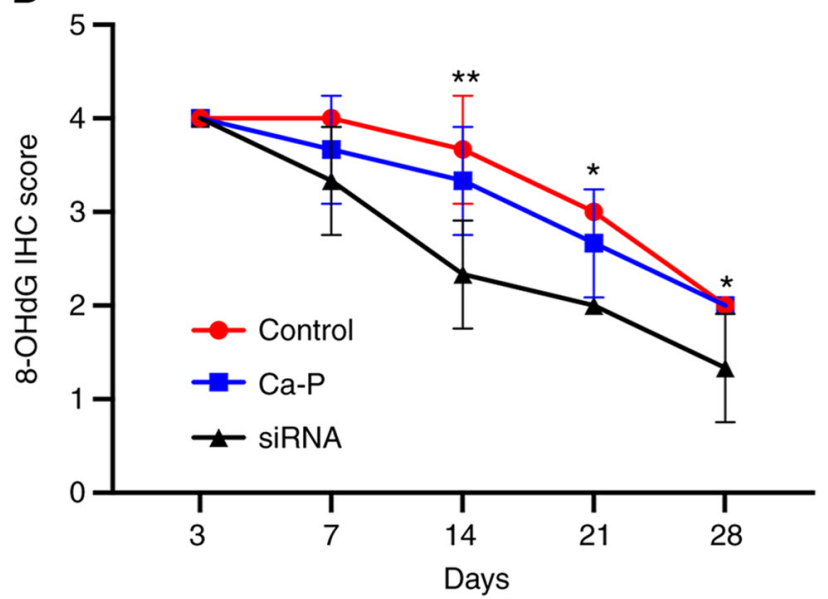

$\mathrm{F}$

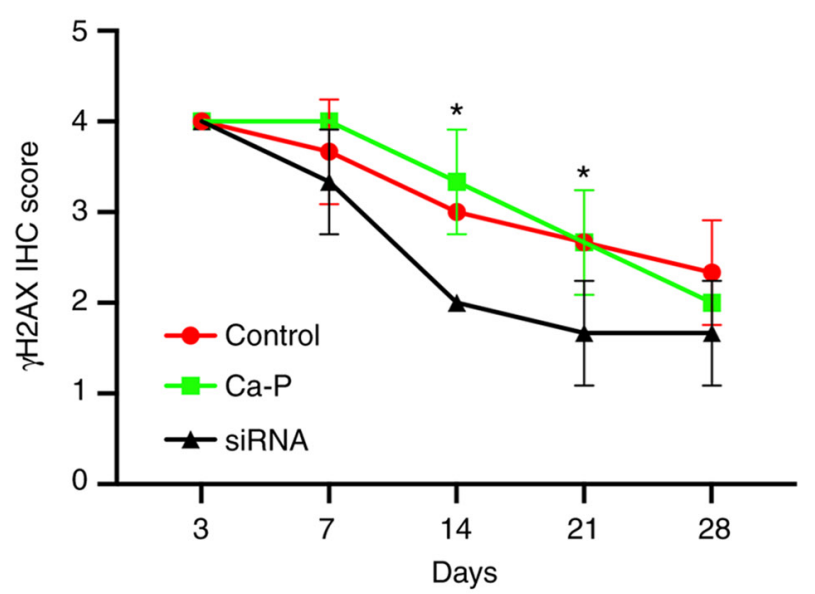

Figure 3. H\&E staining and 8-OHdG and $\gamma \mathrm{H} 2 \mathrm{AX}$ immunohistochemical staining to assess burn wound healing in rats treated daily with 150 nanomolar $\mathrm{B} 1$ siRNA. (A) Sections of tissue immunostained with H\&E after 14 days of wounding and healing. (B) Pathological wound healing scores of six second-degree burn wounds/timepoint. (C) Sections of wounded tissues immunostained for 8-OHdG after 7 and 14 days. (D) Quantification of 8-OHdG staining. (E) Sections of wound tissue immunostained for $\gamma \mathrm{H} 2 \mathrm{AX}$ after 7 and 14 days. (F) Quantification of $\gamma \mathrm{H} 2 \mathrm{AX}$ (one-way ANOVA). ${ }^{*} \mathrm{P}<0.05$, ${ }^{* *} \mathrm{P}<0.01$. H\&E, hematoxylin and eosin; 8-OHdG, 8-Hydroxy-2'-deoxyguanosine; $\gamma \mathrm{H} 2 \mathrm{AX}$, histone H2AX phosphorylated on serine 139; siRNA, small interfering RNA; Ca-P, calcium phosphate.

$4.0 \pm 0.0$ vs. $3.33 \pm 0.58 \%$, both $P>0.05$, iii) day $14,3.0 \pm 0.0$ and $3.33 \pm 0.58$ vs. $2.67 \pm 0.58 \%$, both $\mathrm{P}<0.05$, iv) day $21,2.67 \pm 0.58$ and $2.67 \pm 0.58$ vs. $2.0 \pm 0.0 \%$, both $\mathrm{P}<0.05$; and v) day $28,2.0 \pm 0.0$ and $2.0 \pm 0.0$ vs. $1.67 \pm 0.58 \%$; both $\mathrm{P}>0.05$ (Fig. $3 \mathrm{E}$ and F).

\section{Discussion}

The healing of burn wounds requires the synchronous activity of numerous intricate molecular processes, such as cell 
creeping and epithelialization, neoangiogenesis and fibroblast remodeling (61). Global DNA hypomethylation causes delayed wound healing; therefore, we induced hypermethylation of IRSs to promote the wound healing process (62).

A limitation of this study is that we performed only in vitro experiments with the scrambled siRNA; an in vivo scrambled siRNA control group was not included. B1 siRNA significantly increased B1 methylation, whereas the scrambled siRNA marginally increased B1 methylation. There were no off-target effects in the scrambled siRNA group in the in vitro experiment Fig. S1).

In the animal model experiments, 7-28 days post-injury, the B1 siRNA-treated group showed faster wound-contracture and re-epithelialization rates than the control group. An examination of wound tissue sections also revealed that treatment with B1 siRNA induced favorable pathological alterations in the repaired tissues. The ability of B1 siRNA to increase the B1 methylation levels and heal thermally-induced injury corresponded with a significant decrease in DNA damage responses, based on $8-\mathrm{OHdG}$ and $\gamma \mathrm{H} 2 \mathrm{AX}$ scores in the wound tissues.

A previous in vitro study showed that increased Alu methylation increases a cells tolerance to toxic substances and also increases the proliferation of these cells (15). A molecular substance that can manage DNA methylation at a precise target, reduce DNA damage responses, stabilize the genome and improve second-degree burn wound healing in a rat model was developed by in the present study. B1 siRNA specifically increased the methylation of $\mathrm{B} 1$ repetitive sequences by RNA-directed DNA methylation $(23,63)$. DNA damage responses can lead to mutations and delay cell cycle progression or cause cell cycle arrest $(64,65)$. Therefore, the reduction in DNA damage responses, as assessed using $8-\mathrm{OHdG}$ and $\gamma \mathrm{H} 2 \mathrm{AX}$ scores, induced by increased B1 methylation using B1 siRNA, led to increased wound contraction rates and improved overall pathological scores in the wounded sections. Reduced inflammation, greater epithelialization, new collagen deposition, fibroblast migration and new blood vessel growth were also observed (data not shown).

Following radiation exposure, DNA methylation is reduced in mice heart muscles owing to DNA damage responses and release of free radicals; how B1 methylation decreases DNA damage responses remains to be determined (66). It is not clear how B1 siRNA can accelerate burn wound healing and reduce DNA damage responses; based the results of the present study, it is hypothesized that IRS methylation is associated with other epigenetic phenomena, such as the formation of heterochromatin $(67,68)$. Therefore, heterochromatin may protect DNA from damage and damage responses, and downregulate DNA replication and transcription processes (69). Another possibility is that a change in the chromatin form could ameliorate DNA repair activity $(70,71)$. This process might reduce DNA damage response in the heterochromatin region altered by B1 hypermethylation. Enhanced B1 methylation might lower oxidative stress and, consequently, DNA damage. Alu hypermethylation is correlated with weight gain in infants during the first year of birth (72). Conversely, the association between Alu hypomethylation with DNA damage and lesions demonstrates that Alu hypomethylation increases the risk of non-communicable diseases, such as diabetes mellitus, hypertension and osteoporosis (73-75).

In summary, B1 siRNA can promote healing of second-degree burn wounds in rats by increasing the epithelialization rate, improving pathological scores and accelerating the wound healing rate. These results indicate that B1 siRNA promotes wound healing by reducing the DNA damage response and enhancing global DNA methylation. B1 siRNA assisted in genomic recovery and improved the healing process of second-degree burn wounds in rats; this suggests that B1 siRNA may serve as a novel treatment method for burn wounds in clinical practice, perhaps as a topical agent against repetitive sequences. Further studies to evaluate the efficacy of B1 siRNA against different types of burns with different severities will be highly beneficial for determining the clinical potential of this treatment.

\section{Acknowledgements}

We would like to thank Dr Manita Attasuriyanan and Dr Apasee Sooksamran, Division of Dermatology, Department of Medicine, Faculty of Medicine, Chulalongkorn University, Bangkok for assistance with the pathological scoring.

\section{Funding}

This work was supported by the Faculty of medicine, Chulalongkorn University, the Thailand Research Fund (grant no. RSA 6280053) and the National Science and Technology Development Agency (grant no. FDA-CO-2561-8477-TH).

\section{Availability of data and materials}

The datasets used and/or analyzed during the present study are available from the corresponding author on reasonable request.

\section{Authors' contributions}

JM, AA, KJH and AM conceived the study. JM, PN, AA and AM curated the data. JM, JW, NK, KJH, AA and AM analyzed the data. JM, PN, JW, AM and AA performed the investigation. JM, JW, NK, KJH, AM and AA designed the study. JM, JW, NK drafted the manuscript. JM, JW, NK, KJH, $\mathrm{AM}$ and AA review and edited the manuscript. All authors have read and approved the manuscript. $\mathrm{KJH}, \mathrm{AM}$ and $\mathrm{AA}$ confirm the authenticity of all the raw data.

\section{Ethics approval and consent to participate}

Animal experiments were approved by the Animal Care and Use Committee of Chulalongkorn University (approval no. 003/2562).

\section{Patient consent for publication}

Not applicable.

\section{Competing interests}

The authors declare that they have no competing interests.

\section{References}

1. Chen L, He X, Xian J, Liao J, Chen X, Luo Y, Wang Z and Li N: Development of a framework for managing severe burns through a 17-year retrospective analysis of burn epidemiology and outcomes. Sci Rep 11: 9374, 2021. 
2. Veniaminova NA, Vassetzky NS and Kramerov DA: B1 SINEs in different rodent families. Genomics 89: 678-686, 2007.

3. Gaudet F, Hodgson JG, Eden A, Jackson-Grusby L, Dausman J, Gray JW, Leonhardt $\mathrm{H}$ and Jaenisch R: Induction of tumors in mice by genomic hypomethylation. Science 300: 489-492, 2003

4. Slimen IB, Najar T, Ghram A, Dabbebi H, Ben Mrad M and Abdrabbah M: Reactive oxygen species, heat stress and oxidative-induced mitochondrial damage. A review. Int J Hyperthermia 30: 513-523, 2014.

5. Gebhard W, Meitinger T, Höchtl J and Zachau HG: A new family of interspersed repetitive DNA sequences in the mouse genome. J Mol Biol 157: 453-471, 1982.

6. Batzer MA and Deininger PL: Alu repeats and human genomic diversity. Nat Rev Genet 3: 370-379, 2002.

7. Tsirigos A and Rigoutsos I: Alu and b1 repeats have been selectively retained in the upstream and intronic regions of genes of specific functional classes. PLoS Comput Biol 5: e1000610, 2009

8. Roman AC, Benitez DA, Carvajal-Gonzalez JM and Fernandez-Salguero PM: Genome-wide B1 retrotransposon binds the transcription factors dioxin receptor and Slug and regulates gene expression in vivo. Proc Natl Acad Sci USA 105: $1632-1637,2008$

9. Román AC, González-Rico FJ and Fernández-Salguero PM B1-SINE retrotransposons: Establishing genomic insulatory networks. Mob Genet Elements 1: 66-70, 2011.

10. Ti D, Li M, Fu X and Han W: Causes and consequences of epigenetic regulation in wound healing. Wound Repair Regen 22 305-312, 2014

11. Mutirangura A: A hypothesis to explain how the DNA of elderly people is prone to damage: Genome-wide hypomethylation drives genomic instability in the elderly by reducing youth-associated genome-stabilizing DNA gaps. In: Epigenetics. Meccariello R (ed). IntechOpen, London, 2018.

12. Bollati V, Schwartz J, Wright R, Litonjua A, Tarantini L, Suh H, Sparrow D, Vokonas P and Baccarelli A: Decline in genomic DNA methylation through aging in a cohort of elderly subjects. Mech Ageing Dev 130: 234-239, 2009.

13. Li Y, Sawalha AH and Lu Q: Aberrant DNA methylation in skin diseases. J Dermatol Sci 54: 143-149, 2009.

14. Udomsinprasert W, Kitkumthorn N, Mutirangura A, Chongsrisawat V, Poovorawan Y and Honsawek S: Global methylation, oxidative stress, and relative telomere length in biliary atresia patients. Sci Rep 6: 26969, 2016.

15. Patchsung M, Settayanon S, Pongpanich M, Mutirangura D, Jintarith P and Mutirangura A: Alu siRNA to increase Alu element methylation and prevent DNA damage. Epigenomics 10 $175-185,2018$

16. Luo G, Jing X, Yang S, Peng D, Dong J, Li L, Reinach PS and Yan D: DNA methylation regulates corneal epithelial wound healing by targeting miR-200a and CDKN2B. Invest Ophthalmol Vis Sci 60: 650-660, 2019.

17. Plikus MV, Guerrero-Juarez CF, Treffeisen E and Gay DL: Epigenetic control of skin and hair regeneration after wounding. Exp Dermatol 24: 167-170, 2015

18. Aguilar C and Gardiner DM: DNA methylation dynamics regulate the formation of a regenerative wound epithelium during axolotl limb regeneration. PLoS One 10: e0134791, 2015.

19. Erichsen L, Beermann A, Arauzo-Bravo MJ, Hassan M Dkhil MA, Al-Quraishy S, Hafiz TA, Fischer JC and Santourlidis S: Genome-wide hypomethylation of LINE-1 and Alu retroelements in cell-free DNA of blood is an epigenetic biomarker of human aging. Saudi J Biol Sci 25: 1220-1226, 2018

20. Mutirangura A: Is global hypomethylation a nidus for molecular pathogenesis of age-related noncommunicable diseases? Epigenomics 11: 577-579, 2019 .

21. Erdmann RM and Picard CL: RNA-directed DNA methylation. PLoS Genet 16: e1009034, 2020.

22. Castanotto D, Tommasi S, Li M, Li H, Yanow S, Pfeifer GP and Rossi JJ: Short hairpin RNA-directed cytosine $(\mathrm{CpG})$ methylation of the RASSF1A gene promoter in HeLa cells. Mol Ther 12 $179-183,2005$

23. Matzke MA and Mosher RA: RNA-directed DNA methylation: An epigenetic pathway of increasing complexity. Nat Rev Genet 15: 394-408, 2014.

24. Mathieu O and Bender J: RNA-directed DNA methylation. J Cell Sci 117: 4881-4888, 2004

25. Reis AH, Vargas FR and Lemos B: Biomarkers of genome instability and cancer epigenetics. Tumour Biol 37: 13029-13038, 2016

26. Kongruttanachok N, Phuangphairoj C, Thongnak A, Ponyeam W, Rattanatanyong $\mathrm{P}$, Pornthanakasem $\mathrm{W}$ and Mutirangura $\mathrm{A}$ Replication independent DNA double-strand break retention may prevent genomic instability. Mol Cancer 9: 70, 2010
27. Takahashi A, Matsumoto H, Nagayama K, Kitano M, Hirose S, Tanaka H, Mori E, Yamakawa N, Yasumoto J, Yuki K, et al: Evidence for the involvement of double-strand breaks in heat-induced cell killing. Cancer Res 64: 8839-8845, 2004.

28. Mah LJ, El-Osta A and Karagiannis TC: gammaH2AX: A sensitive molecular marker of DNA damage and repair. Leukemia 24: 679-686, 2010

29. Mataix M, Rodríguez-Luna A, Gutiérrez-Pérez M, Milani M, Gandarillas A, Espada J and Pérez-Davó A: Deschampsia antarctica extract (Edafence ${ }^{\circledR}$ ) as a powerful skin protection tool against the aging exposome. Plast Aesthet Res 7: 69, 2020.

30. Korkmaz KS, Debelec Butuner B and Roggenbuck D: Detection of 8-OHdG as a diagnostic biomarker. J Lab Precis Med 3: 95, 2018.

31. Purschke M, Laubach HJ, Anderson RR and Manstein D: Thermal injury causes DNA damage and lethality in unheated surrounding cells: Active thermal bystander effect. J Invest Dermatol 130: 86-92, 2010

32. Houston BJ, Nixon B, Martin JH, De Iuliis GN, Trigg NA, Bromfield EG, McEwan KE and Aitken RJ: Heat exposure induces oxidative stress and DNA damage in the male germ line. Biol Reprod 98: 593-606, 2018.

33. Hintzsche H, Riese T and Stopper H: Hyperthermia-induced micronucleus formation in a human keratinocyte cell line. Mutat Res 738-739: 71-74, 2012.

34. Firsanov DV, Solovjeva LV and Svetlova MP: H2AX phosphorylation at the sites of DNA double-strand breaks in cultivated mammalian cells and tissues. Clin Epigenetics 2: 283-297, 2011.

35. Kinner A, Wu W, Staudt C and Iliakis G: Gamma-H2AX in recognition and signaling of DNA double-strand breaks in the context of chromatin. Nucleic Acids Res 36: 5678-5694, 2008.

36. Kaneko H, Igarashi K, Kataoka K and Miura M: Heat shock induces phosphorylation of histone $\mathrm{H} 2 \mathrm{AX}$ in mammalian cells. Biochem Biophys Res Commun 328: 1101-1106, 2005.

37. Dewhirst MW, Lora-Michiels M, Viglianti BL, Dewey WC and Repacholi M: Carcinogenic effects of hyperthermia. Int J Hyperthermia 19: 236-251, 2003.

38. Xu R, Li S, Guo S, Zhao Q, Abramson MJ, Li S and Guo Y: Environmental temperature and human epigenetic modifications: A systematic review. Environ Pollut 259: 113840, 2020.

39. Bind MC, Coull BA, Baccarelli A, Tarantini L, Cantone L, Vokonas $\mathrm{P}$ and Schwartz J: Distributional changes in gene-specific methylation associated with temperature. Environ Res 150: 38-46, 2016

40. Hao Y, Cui Y and Gu X: Genome-wide DNA methylation profiles changes associated with constant heat stress in pigs as measured by bisulfite sequencing. Sci Rep 6: 27507, 2016 .

41. Varriale A and Bernardi G: DNA methylation and body temperature in fishes. Gene 385: 111-121, 2006.

42. Vinoth A, Thirunalasundari T, Shanmugam M, Uthrakumar A Suji S and Rajkumar U: Evaluation of DNA methylation and mRNA expression of heat shock proteins in thermal manipulated chicken. Cell Stress Chaperones 23: 235-252, 2018.

43. Bind MA, Zanobetti A, Gasparrini A, Peters A, Coull B, Baccarelli A, Tarantini L, Koutrakis P, Vokonas P and Schwartz J: Effects of temperature and relative humidity on DNA methylation. Epidemiology 25: 561-569, 2014.

44. Dridi S: Alu mobile elements: From junk DNA to genomic gems. Scientifica (Cairo) 2012: 545328, 2012.

45. Marquardt N, Feja M, Hünigen H, Plendl J, Menken L, Fink H and Bert B: Euthanasia of laboratory mice: Are isoflurane and sevoflurane real alternatives to carbon dioxide? PLoS One 13: e0203793, 2018.

46. Cai EZ, Ang CH, Raju A, Tan KB, Hing EC, Loo Y, Wong YC, Lee H, Lim J, Moochhala SM, et al: Creation of consistent burn wounds: A rat model. Arch Plast Surg 41: 317-324, 2014.

47. Zhao D, Wang CQ, Zhuo RX and Cheng SX: Modification of nanostructured calcium carbonate for efficient gene delivery. Colloids Surf B Biointerfaces 118: 111-116, 2014

48. Wu X, Yamamoto H, Nakanishi H, Yamamoto Y, Inoue A, Tei M, Hirose H, Uemura M, Nishimura J, Hata T, et al: Innovative delivery of siRNA to solid tumors by super carbonate apatite. PLoS One 10: e0116022, 2015

49. Mostaghaci B, Loretz B and Lehr CM: Calcium phosphate system for gene delivery: Historical background and emerging opportunities. Curr Pharm Des 22: 1529-1533, 2016.

50. Xie Y, Chen Y, Sun M and Ping Q: A mini review of biodegradable calcium phosphate nanoparticles for gene delivery. Curr Pharm Biotechnol 14: 918-925, 2013.

51. Xu X, Li Z, Zhao X, Keen L and Kong X: Calcium phosphate nanoparticles-based systems for siRNA delivery. Regen Biomater 3: 187-195, 2016. 
52. Levingstone TJ, Herbaj S, Redmond J, McCarthy HO and Dunne NJ: Calcium phosphate nanoparticles-based systems for RNAi delivery: Applications in bone tissue regeneration. Nanomaterials (Basel) 10: 146, 2020.

53. Wang F, Zieman A and Coulombe PA: Skin keratins. Methods Enzymol 568: 303-350, 2016.

54. Tanideh N, Rokhsari P, Mehrabani D, Mohammadi Samani S, Sabet Sarvestani F, Ashraf MJ, Koohi Hosseinabadi O, Shamsian S and Ahmadi N: The healing effect of licorice on Pseudomonas aeruginosa infected burn wounds in experimental rat model. World J Plast Surg 3: 99-106, 2014.

55. Farghali HA, Abdelkader NA, Khattab MS and Abubakr HO Evaluation of subcutaneous infiltration of autologous platelet-rich plasma on skin-wound healing in dogs. Biosci Rep 37: BSR20160503, 2017.

56. Tavares Pereira Ddos S, Lima-Ribeiro MH, De Pontes-Filho NT, Carneiro-Leão AM and Correia MT: Development of animal model for studying deep second-degree thermal burns. J Biomed Biotechnol 2012: 460841, 2012.

57. Haghdoost F, Baradaran Mahdavi MM, Zandifar A, Sanei MH, Zolfaghari B and Javanmard SH: Pistacia atlantica resin has a dose-dependent effect on angiogenesis and skin burn wound healing in rat. Evid Based Complement Alternat Med 2013: $893425,2013$.

58. Edraki M, Akbarzadeh A, Hosseinzadeh M, Tanideh N, Salehi A and Koohi-Hosseinabadi O: Healing effect of sea buckthorn, olive oil, and their mixture on full-thickness burn wounds. Adv Skin Wound Care 27: 317-323, 2014

59. Ahmed I, Islam M, Arshad W, Mannan A, Ahmad W and Mirza B: High-quality plant DNA extraction for PCR: An easy approach. J Appl Genet 50: 105-107, 2009.

60. Untergasser A, Cutcutache I, Koressaar T, Ye J, Faircloth BC Remm M and Rozen SG: Primer3-New capabilities and interfaces. Nucleic Acids Res 40: e115, 2012.

61. Rowan MP, Cancio LC, Elster EA, Burmeister DM, Rose LF Natesan S, Chan RK, Christy RJ and Chung KK: Burn wound healing and treatment: Review and advancements. Crit Care 19: $243,2015$.

62. Lewis CJ, Mardaryev AN, Sharov AA, Fessing MY and Botchkarev VA: The epigenetic regulation of wound healing. Adv Wound Care (New Rochelle) 3: 468-475, 2014.

63. Chalertpet K, Pin-On P, Aporntewan C, Patchsung M, Ingrungruanglert $\mathrm{P}$, Israsena $\mathrm{N}$ and Mutirangura $\mathrm{A}$ : Argonaute 4 as an effector protein in RNA-directed DNA methylation in human cells. Front Genet 10: 645, 2019.
64. Kantidze OL, Velichko AK, Luzhin AV and Razin SV: Heat stress-induced DNA damage. Acta Naturae 8: 75-78, 2016.

65. Velichko AK, Petrova NV, Razin SV and Kantidze OL: Mechanism of heat stress-induced cellular senescence elucidates the exclusive vulnerability of early S-phase cells to mild genotoxic stress. Nucleic Acids Res 43: 6309-6320, 2015.

66. Koturbash I, Miousse IR, Sridharan V, Nzabarushimana E, Skinner CM, Melnyk SB, Pavliv O, Hauer-Jensen M, Nelson GA and Boerma M: Radiation-induced changes in DNA methylation of repetitive elements in the mouse heart. Mutat Res 787: 43-53, 2016.

67. Baylin SB, Esteller M, Rountree MR, Bachman KE, Schuebel K and Herman JG: Aberrant patterns of DNA methylation, chromatin formation and gene expression in cancer. Hum Mol Genet 10: 687-692, 2001.

68. Kim JH: Chromatin remodeling and epigenetic regulation in plant DNA damage repair. Int J Mol Sci 20: 4093, 2019.

69. Grewal SI and Jia S: Heterochromatin revisited. Nat Rev Genet 8: 35-46, 2007.

70. Xu Y, Xu C and Price BD: Mechanistic links between ATM and histone methylation codes during DNA repair. Prog Mol Biol Transl Sci 110: 263-288, 2012.

71. Jakob B, Splinter J, Conrad S, Voss KO, Zink D, Durante M, Löbrich $\mathrm{M}$ and Taucher-Scholz G: DNA double-strand breaks in heterochromatin elicit fast repair protein recruitment, histone H2AX phosphorylation and relocation to euchromatin. Nucleic Acids Res 39: 6489-6499, 2011.

72. Rerkasem K, Rattanatanyong P, Rerkasem A, Wongthanee A, Rungruengthanakit K, Mangklabruks A and Mutirangura A: Higher Alu methylation levels in catch-up growth in twenty-year-old offsprings. PLoS One 10: e0120032, 2015.

73. Jintaridth $P$, Tungtrongchitr R, Preutthipan S and Mutirangura A Hypomethylation of Alu elements in post-menopausal women with osteoporosis. PLoS One 8: e70386, 2013.

74. Thongsroy J, Patchsung M and Mutirangura A: The association between Alu hypomethylation and severity of type 2 diabetes mellitus. Clin Epigenetics 9: 93, 2017.

75. Han L, Liu Y, Duan S, Perry B, Li W and He Y: DNA methylation and hypertension: Emerging evidence and challenges. Brief Funct Genomics 15: 460-469, 2016.

(7) $\odot$ This work is licensed under a Creative Commons Attribution-NonCommercial-NoDerivatives 4.0 International (CC BY-NC-ND 4.0) License. 